\title{
Analysis of The Influence of Pentagon Fraud in Detecting Financial Statement Fraud Using Method F- Score
}

\author{
(Empirical Study on Manufacturing Companies Listed on Stock Exchange \\ Indonesia 2015-2019 Period) \\ Vina Yusniarti*, Henny Mulyati, Amrizal \\ vina.yusniarti@gmail.com,Hennyml@itb-ad.ac.id, amrizal@itb-ad.ac.id \\ Institut Teknologi dan Bisnis Ahmad Dahlan, Jalan Ir H. Juanda No.77, Cireundeu, Kec. Ciputat Timur, \\ Kota Tangerang Selatan, Banten 15419
}

\begin{abstract}
This study aims to examine the elements of fraud in the fraud pentagon theory in detecting financial statement fraud. Pentagon fraud is variables from the pressure element, opportunity, rationalization, capability, and elements of arrogance, namely political relationships which are hypothesized to affect financial statement fraud. The F-Score method is used to determine financial statement fraud. This research sample was selected using the purposive sampling method from 47 manufacturing companies in the basic industry and chemicals industry listed on the Indonesia Stock Exchange (BEI) in the period 2015 to 2019. Hypothesis testing uses multiple regression analysis models using SPSS 22 to test the effect of the target. finance, financial stability, external pressure, institutional share ownership, ineffective supervision, influence on the nature of the industry, quality of external auditors, replacement of auditors, change of directors and political relations to financial statement fraud. The results showed that the quality of external auditors and auditor turnover had a significant positive effect on financial statement fraud. Meanwhile, financial targets, financial stability, external pressure, institutional share ownership, ineffective supervision, the influence of the nature of the industry, the change of directors, and political relations have no effect on financial statement fraud.
\end{abstract}

Keywords: financial statement fraud, pentagon fraud.

\section{Introduction}

"Association of Certified Fraud Examiners (ACFE) [1] says in the chart acts commit fraud called" fraud tree" . Fraud tree aka the branch of fraud consists of three branches, namely misuse of assets, fraud in financial reports, and corruption. The three schemes behavior of cheating that applied management and employees in the company. This chart was introduced in 1996 and is still being refined. Association of Certified Fraud Examiners (ACFE) [1] in acts of fraud are activities that a person or entity to commit fraud or irregularities conscious and knowing that irregularities can download the emergence of damages to individuals or entities or any other party [2].

The truth that the manufacturing industry is one of the many industries The truth is that the 


\section{Procedia of Social Sciences and Humanities \\ ISSN (online) 2722-0672 \\ https://pssh.umsida.ac.id/index.php/pssh}

manufacturing industry is one of the most fraudulent industries, namely $17 \%$ of 38 cases obtained from a survey conducted by the Association of Certified Fraud Examiner (ACFE) [1]. The diagram below is a comparison with other sectors affected by fraud:

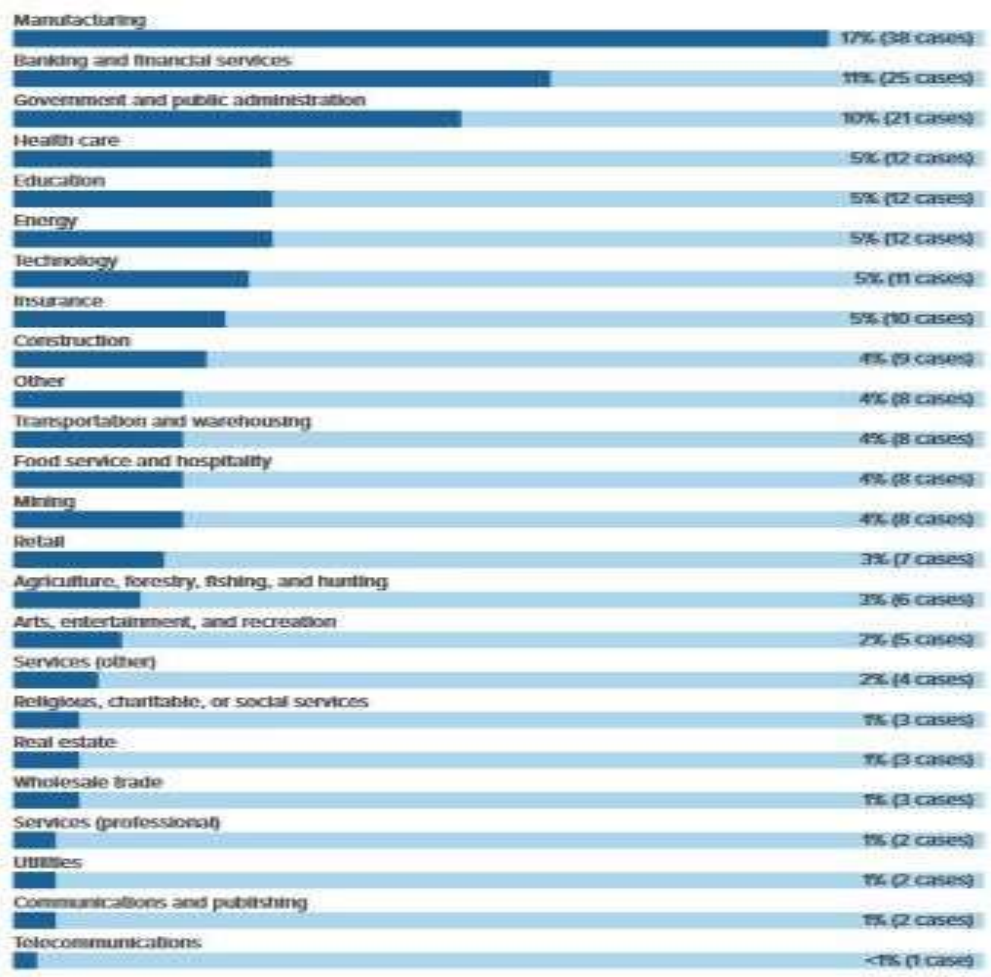

Source : Association of Certified Fraud Examiner (2018)

Fig. 1.1. Industry of Victim Organizations

Cheating financial statements in the year 2018 increased to $13 \%$ compared to the right in 2016 only by $9,6 \%$. This event is caused in the manufacturing industry, inventory is a sensitive account to the act of fraud. The other thing is caused, the emergence of receivables doubtful is the shape estimate that the cause of the sensitivity of fraud in industrial manufacturing. Financial statement fraud is one of the problems that cannot be considered easily resolved by ACFE [1]. Making decisions that are irrelevant and unreliable will have an impact on the information needed by stakeholders. The result of fraudulent behavior in the financial statements will have an impact on greater losses $(\$ 700,000)$ than the misuse of assets and corruption that occurred in 2018 of $80 \%$ and $51 \%$ with the impact of losses of $\$ 180,000$ and $\$ 500,000$ by ACFE [1]. The resulting losses incurred by the lower-middle management and employees were \$323,000 and \$ 58,000 .

Based on the results of previous research which states that the results of the Fraud Pentagon research, which are proxied by ten variables, consist of three elements of pressure (financial target, financial stability, external pressure), two variables of the opportunity element (ineffective monitoring and nature of industry), one variable of rationalization element (change in auditor), one variable of capability element (change in directors), and 


\section{Procedia of Social Sciences and Humanities \\ ISSN (online) 2722-0672 \\ https://pssh.umsida.ac.id/index.php/pssh}

three variables of arrogance element (frequent number of CEO's pictures, political connection, and dualism position) which are hypothesized to influence financial statement fraud by Cintia Zelin [3].

This research is motivated by the worrying condition of the number of fraudulent financial reporting cases in Indonesia, if seen from the number of cases on indications of fraud occurring globally, it is very high every year and until now there is still no appropriate corrective action to solve this problem. And also until now there is still little research done to thoroughly analyze this case, especially by using Crowe's fraud pentagon theory. What distinguishes this research from previous research is the independent variable, year and also the sample used. This study combines variables from previous studies and examines the factors of the pentagon fraud theory with a longer research period of 5 (five) years from the 2015-2019 period, because the previous research period ranged from a maximum to 3 (years). And in this study using a sample of manufacturing companies in the basic industry and chemicals sector which are listed on the Indonesia Stock Exchange (BEI). From this background description, the researcher is interested in conducting research with the title "Analysis of the Effect of Pentagon Fraud in Detecting Fraud Financial Statements Using the F-Score Method (Empirical Study of Manufacturing Companies Listed on the Indonesia Stock Exchange 2015-2019 Period )".

\subsection{Literature Review Agency Theory}

"The theory of agency is the relationship of the onset of separation between ownership and management is done by the manager, an agency relationship arises if one or more individuals who are called principals, employing one or another individual, called the agent, to undertake various activities of the operational activities of the company on behalf of principals in capacity to take a decision by Jensen and Meckling [4].

\section{Fraud Theory}

"Cheating (fraud) is the deliberate act done with the intent to deceive and manipulate personal, company, or organization for personal gain. Meanwhile, according to the " Association of Certified Fraud Examiners (ACFE) defines fraud (fraud) as a fraudulent act made by a person or entity who knows that the mistake can result in losses to individuals or other entities. Fraudulent Financial Reporting $(F F R)$ or fraudulent financial statements are described by the Association of Certified Fraud Examiners by ACFE [1].

\section{Financial Statement Fraud (Fraudulent Financial Statement)}

"Fraud financial reporting (Financial Statement Fraud) is a misstatement or omission of amounts or intentional disclosures with the intention of deceiving the users of the report. Most of the cases involved intentional misstatement of amounts, not disclosures. For example, WorldCom is reported to have capitalized billions of dollars as fixed assets, which should be charged. Unusual amount of negligence has been committed, but companies may have overstated their profit by ignoring trade payables and other liabilities by Alvin A. Arens, Randal J. Elder, Mark S. Beasley [5].

\section{Pentagon Fraud Theory}

"The latest development of the fraud model discovered by Jonathan Marks in 2012 is known as Crowe's Fraud Pentagon Theory. The fraud pentagon theory develops the fraud triangle theory by adding two other elements of fraud, namely competence and arrogance by Cressey [6]. 


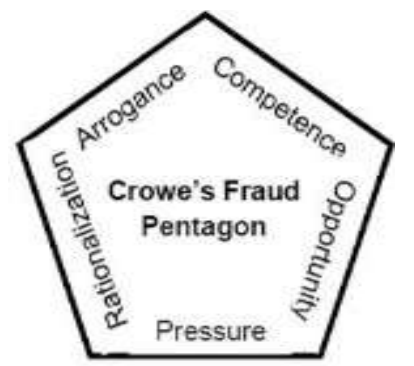

Source : Crowe's fraud pentagon theory (Crowe, 2011)

Fig. 2.1 Pentagon fraud

\section{Fraud Score Model (F-Score)}

"The F-Score model is the sum of two variables, namely accrual quality and financial performance by Skousen and Twedt, [7]. The F-Score model is the sum of two variables, namely accrual quality and financial performance, namely:

\section{F- Score $=$ Accrual Quality + Financial Performance}

This model is a model of detection of acts of fraud financial statements were developed using techniques scaled logistic probability by Dechow et al [8].

\subsection{Previous Research}

Research conducted by Ema Heviana [9] found that financial stability and effective monitoring have an effect on fraudulent financial reporting. Financial targets, external pressure, institutional ownership, change in auditors, change of directors, and frequent number of CEO's picture have no effect on fraudulent financial reporting.

Research conducted by Cintia Zelin [3] shows that financial targets and financial stability have a significant positive effect on financial statement fraud. Meanwhile, external pressures, ineffective supervision, the influence of the nature of the industry, changes in auditors, changes in directors, the number of photos displayed, political relations, and dualism of positions did not affect financial statement fraud.

Research conducted by Indar Satria Legowo [10] obtained results that show fraud pentagon factors, namely pressure which is proxied on external pressure and financial stability, opportunity which is proxied on the quality of external auditors and arrogance which is proxied on the frequency of appearance of CEO photos has a significant effect on fraudulent financial reporting . Meanwhile, the pentagon fraud factor, namely the ratio analysis proxied in the audit opinion, the proxied competence in the change of directors and the expertise of the audit committee have no effect on fraudulent financial reporting.

Research conducted by Galih Devi Saptarini [11] shows that the financial target and capability variables are proven to have a significant positive effect in detecting potential fraudulent financial statements. Meanwhile, variable pressure is represented by external pressure; opportunity variable which is proxied by nature of industry and effective monitoring; rationalization variable; and arrogance variable has no effect in detecting potential fraud in financial statements. 


\section{Procedia of Social Sciences and Humanities \\ ISSN (online) 2722-0672 \\ https://pssh.umsida.ac.id/index.php/pssh}

\subsection{Research Conceptual Framework}

The framework of the research process on financial statement fraud using the fraud pentagon approach can be seen in Figure 2.2 The elements of the fraud pentagon cannot be measured directly. Therefore, the measurement of the fraud pentagon element uses a proxy variable. Pressure is measured using the variable financial target, financial stability, external pressure, and institutional ownership. Opportunity was measured using a variable ineffective monitoring, the nature of industr $\boldsymbol{y}$ and quality of external auditors, rationalization measured using a variable change in auditor, Capability / Competence is measured using a variable change in directors, and Arogance measured using variables $p$ olitical connection. The conceptual framework in this study can be described in the following figure:

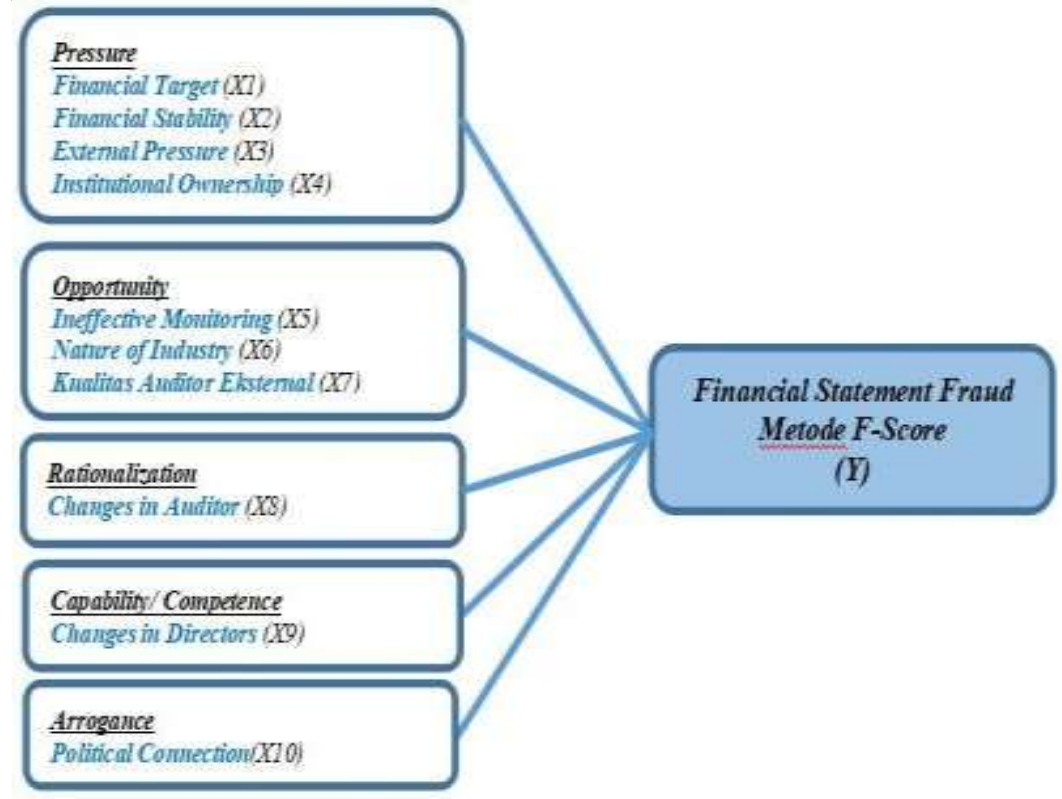

Figure.2.2 Framework

\subsection{Hypothesis}

Risk effect factor of pressure (financial targets, financial stability, external pressure, and institutional ownership) to financial statement fraud.

Pressure is the encouragement of people to commit fraud. In general, pressure arises because of financial needs or problems, but many are only driven by greed by Priantara [12]. Financial Target is a level of profit that will be achieved for the business issued by Rahmanti [13]. Financial Stability is a condition in which the economic mechanism in pricing, allocation of funds and risk management functions properly and supports economic growth or it can also be interpreted as avoiding a company from a monetary or financial crisis by Rahmanti [13]. External Pressure External pressure is a situation where the company is under pressure from outside the company. Pressure from external parties to get additional debt or sources of funds from external parties to remain competitive. To get funds from external parties, the company must display good financial and profit ratio performance so that investors are interested. In addition, the company must be believed to be able to repay the loan it has received. Therefore this encourages managers to manipulate by Sihombing and Raharjo, [14]. 
Institutional Ownership is the percentage of certain shares owned by an institution that can affect the process of preparing financial statements which does not rule out accrualization in accordance with the interests of the management in by Nuraina, [15]. Previous research conducted by Cintia Zelin [3] shows that financial targets and financial stability have a significant positive effect on fraudulent financial statements. Meanwhile, external pressure has no effect on fraudulent financial statements. From the results of research conducted by Ema Heviana [9], which concluded that institutional ownership has no influence on fraudulent financial reporting.

H $_{1}$ : Pressure on the proxy variable, financial target, financial stability, external pressure, and institutional ownership have a significant and positive effect on the detection of financial statement fraud

Risk effect factor and opportunity (effective monitoring, the nature of the industry and the quality of external auditors) to financial financial statement fraud.

Opportunity is an opportunity that allows fraud to occur. Fraud perpetrators believe that their activities will not be detected by Priantara [12]. Ineffective Monitoring is a situation where a company has a supervisory unit that is not effective at monitoring company performance by Priantara [12]. Nature of Industry is an ideal circumstances in an industrial company. Ideally, the condition of a company will certainly benefit a company by Hanifah Agusputri \& Sofie, [16]. Quality of External Auditors good in principle can be achieved if the auditor applying auditing standards and principles, to be free without favoring anyone (independent), pursuant to the law and abide by professional ethics by Priantara [12]. Research conducted by Cintia Zelin [3] shows that the ineffectiveness of supervision, the influence of the nature of the industry, the change of auditors has no effect on fraudulent financial statements.

$\mathrm{H}_{2}$ : Opportunity (opportunities) in the proxy variable ineffective monitoring, nature of industry and $Q$ uality of external auditors significant and positive impact on the detection of financial statement fraud.

Risk factor rationalization (rationalization) in the form of change in the auditor of the financial statement fraud.

Rationalization is justification committed by perpetrators of fraud against fraud done. The perpetrator of fraud will take various measures so that his fraudulent acts are not detected. A form of rationalization that can be carried out by fraudsters is rationalization of subjective judgments by Skousen et al.[17]. The change of the public accounting firm or auditor is carried out to cover or eliminate traces of fraudulent financial statement actions that have been known by the public accounting firm or previous auditors. However, there is also the possibility that the less frequent the company changes auditors, the higher the risk of fraudulent financial reporting, because the company feels that the auditors who handle it are not aware that there are indications of fraudulent financial reporting in the company by Hanifah Agusputri \& Sofie, [16]. Research conducted by Cintia Zelin [3] shows that the change of auditors has no effect on fraudulent financial statements.

$\mathrm{H}_{3}$ : Rationalization on the proxy variable change in auditor has a significant and positive effect on the detection of financial statement fraud. 


\section{Procedia of Social Sciences and Humanities \\ ISSN (online) 2722-0672 \\ https://pssh.umsida.ac.id/index.php/pssh}

Risk factor competency / capability (ability) in the form of change in directors to financial statement fraud.

In the fraud pentagon, this concept considers an individual's ability to be the right person to commit fraud. Capability makes a major contribution as a cause of fraud by Priantara [12]. Generally, companies change directors or change the composition of directors or elect new directors as an effort to improve the performance of the old directors who are considered less competent. However, changing the board of directors can be considered as a way to get rid of the old board of directors who are aware of indications of fraudulent practices in a company by Hanifah Agusputri \& Sofie [16]. Research conducted by Cintia Zelin [3] shows the results that auditor changes have no effect on fraudulent financial statements.

$\mathrm{H}_{4}$ : Competence (ability) on the proxy variable change in directors has a significant and positive effect on the detection of financial statement fraud.

Risk factor arrogance (arrogance) in the form of $p$ olitical connection to financial statement fraud.

Another measure of arrogance is by assessing the political relationships that the board of directors has. One of the advantages if a board of directors has a political relationship is that it is easy to get access to loans from banks, easy to get contracts from the government and if you experience financial distress, you will easily be bailed out by the government by Chaney [18]. Research conducted by Cintia Zelin [3] shows that political relations have no effect on fraudulent financial statements.

$\mathrm{H}_{5}$ : Arogance (Arrogance) on proxy variables political connection is significant and positive impact on the detection of financial statement fraud.

\section{Research Methods}

\subsection{Research Design}

The research design used by the author is an associative research method, namely research that aims to determine the effect and causal relationship between the independent variable and the dependent variable by Sugiyono [19]. In this study associative method used to determine the effect of fraud pentagon tehadap financial statement fraud. Data used in this research is secondary data, namely quantitative data obtained from the Indonesian Stock Exchange (BEI) or www.idx.co.id :

\subsection{Research Object}

The research object that the researchers will use is manufacturing companies in the basic industry and chemicals industry sector with a total sample of 78 manufacturing companies in Indonesia that are listed as go public companies (issuers) on the Indonesia Stock Exchange (BEI) for the 2015-2019 research period.

\subsection{Data Collection Technique}

Data collection techniques in this study are to use documentation and literature study methods. The documentation method is carried out by collecting all secondary data from 


\section{Procedia of Social Sciences and Humanities \\ ISSN (online) 2722-0672 \\ https://pssh.umsida.ac.id/index.php/pssh}

annual reports or annual financial reports (LKT) of go public manufacturing companies that have been published and obtained from the official website of the Indonesia Stock Exchange (BEI), namely www.idx.co.id and also their respective websites. companies during the 2015- 2019 period. The literature study method is carried out using various literatures such as books, research journals, and internet research.

\subsection{Definition of Operationalization of Variables and Their Measurement}

Variabel is constructs (constructs) or properties that will be studied. On the other hand, Kerlinger states that a variable can be said to be a characteristic that is derived from a different value. Thus the variable is a variable. In this study using two variables, namely the dependent and independent variables. Financial statement fraud is the dependent variable in this study. The independent variable of this study was developed from the five components of the fraud pentagon, consisting of pressure, opportunity, rationalization, capability, and arrogance. The research variables will be explained as follows:

Table 3. Ringkasan Variable Operational Research

Fraudulent Financial Reporting (Y)

Financial Target (X1)

Financial Stability $(X 2)$

Eksternal Pressure (X3)

Institutional Ownership (X4)

Ineffective monitoring (X5)

Nature of industry (X6)

Quality of external auditors (X7)

Change in auditor (X8)
Fraud Score Model= Accrual Quality + Financial Performance

$$
R O A=\frac{\text { Earnings After Interest and } \operatorname{Tax}}{\text { Total Assets }}
$$

$$
A C H A N G E=\frac{\text { Total Aset }(t)-\text { Total Aset }(t-1)}{\text { Total Aset }(t-1)}
$$

$$
\text { LEV = Liabilities } / \text { Total Asset }
$$

OSHIP = Shares Owned by Other Institutions / Outstanding Shares

BDOUT $=$ The number of members of the board of independent commissioners / The total number of commissioners

$$
\text { RECEIVABLE }=\frac{\text { Receivable }(t)}{\text { Sales }(t)}-\frac{\text { Receivable }(t-1)}{\text { Sales }(t-1)}
$$

Dummy variable, that is, if the company uses audit services affiliated with BIG-four, it is coded 1

(one) and if the company uses auditing services for non-BIG-four KAPs, it is coded 0 (zero).

Variabel dummy where if there is a change of the Public Accounting Firm (KAP) every year, it is coded 1 (one), otherwise if there is no change of the Public Accounting Firm (KAP) companies then coded 0
Ratio Scale

Ratio Scale

Ratio Scale

Ratio Scale

Ratio Scale

Ratio Scale

Ratio Scale

Nominal Scalel

Nominal Scale 


\section{Procedia of Social Sciences and Humanities \\ ISSN (online) 2722-0672 \\ https://pssh.umsida.ac.id/index.php/pssh}

Director change (X9)

Political connection (X10)
Dummy variable, namely if the company changes directors, it is coded 1 (one) and if the company does not change directors, it will be coded 0 (zero)

Variabel dummy which if there is a board of directors or board of commissioners has political relations within the company every year then coded 1,
Nominal Scale

Nominal Scale

Source : Dechow et al. [8]

\subsection{Data Analysis Method \\ 2.5.1 Descriptive Statistics}

Descriptive statistics are statistics that serve to describe or provide an overview of the object under study through sample or population data as they are, without analyzing and making general conclusions by Sugiyono [20].

\subsubsection{Data Quality Test}

2.5.2.1 Classic assumption test

A good regression model is a regression model that uses a classic assumption test so it is necessary to test the assumptions of normality, multicollinearity, autocorrelation, and heteroscedasticity before testing the hypothesis by Ghozali [21]

\subsubsection{Normality test}

The normality test is used to test whether in the regression model, confounding or residual variables have a normal contribution. This can be detected by analyzing graphs and nonparametric statistical tests of Kolmogorov-Smirnov (KS) by Ghozali [21].

\subsubsection{Multicollinearity Test}

Multicollinearity test serves to test whether the regression model found a relationship or correlation between independent variables. Orthogonal variables are independent variables whose correlation values among independent variables are equal to zero by Ghozali [21].

\subsubsection{Heteroscedasticity Test}

The heteroscedasticity test serves to detect whether it can be done by looking at the presence or absence of a certain pattern on the scatterplot graph between ZPRED and SRESID where the $\mathrm{X}$ axis is the residual that has been studentized and where the $\mathrm{Y}$ axis is $\mathrm{Y}$ which has been predicted by Ghozali [21].

\subsubsection{Autoceralation Test}

A good regression model is free from autocorrelation, to test the presence or absence of an autocorrelation test, the Durbin - Watson test is used which is only used to require intercept (constant) and first order autocorrelation (first order autocorrelation) in the regression model and there are no more variables between variables. independent by Ghozali [21]. The hypotheses to be tested in the autocorrelation test using the Durbin - Watson test are:

$\mathrm{H} 0$ : no autocorrelation $(\mathrm{r}=0)$

$\mathrm{H} 1$ : there is autocorrelation $(\mathrm{r} \neq 0)$ 


\subsection{Hypothesis testing}

\subsubsection{Multiple Linear Regression Test}

Hypothesis testing in this study uses multiple regression analysis method. The multiple linear analysis method aims to examine the effect of two or more independent variables on the dependent variable by Ghozali [22]. The relationship between pentagon fraud and financial statement fraud is measured by the following formula:

F- SCORE = BO + B1ROA + B2ACHANGE + B3LEV + B3OSHIP + B4BDOUT + B5REC + ß6AUD + B6CPA + B7DCHANGE + ß9 POLITICAL + $\varepsilon$

\subsubsection{Statistical test $\mathrm{t}$}

Shows how far the independent variable individually explains variations on the dependent variable or to determine the effect of each independent variable on the dependent variable by Ghozali [21]. Decision-making criteria with a significant level of 5\%. If the value of $t$ $<0.05$, there is a significant effect and if the value of $t>0.05$ then there is no significant effect between one independent variable on the dependent variable.

\subsubsection{Determination Coefficient Test $\left(\mathbf{R}^{2}\right)$}

The coefficient of determination is between zero and one. A small $\mathrm{R}^{2}$ value means that the ability of the independent variables to explain the dependent variable is very limited, on the other hand, if the $\mathrm{R}^{2}$ value approaches one, it means that the independent variables provide almost all the information needed to predict the variation in the dependent variable by Ghozali [21].

\subsubsection{Statistical Test $\mathrm{F}$}

The $\mathrm{F}$ test is carried out to test whether the regression model used is fit. The F test can be done by looking at the $\mathrm{F}$ significance value at the regression output with a significance level of $0.05(\alpha=5 \%)$ if the probability value is greater than $\alpha$, it means that the regression model is not fit. If the probability value is smaller than $\alpha$, it means that the regression value is fit or it can be said that the independent variables jointly affect the dependent variable by Ghozali [22].

\section{Results and Discussion}

The general description of the research object of this study is the presentation of the sample selection procedure and the company groups that are the population of this study. Based on the population of manufacturing companies in the basic industry and chemicals sector listed on the Indonesia Stock Exchange (IDX) for the 2015-2019 period , this study used several samples of manufacturing companies in the basic industry and chemicals sector which were determined based on the purposive sampling method, namely certain criteria. From these considerations, a sample of 78 companies was obtained . Based on these results that the number of companies manufacturing the sector of basic industry and chemicals listed in Indonesia Stock Exchange (BEI) in the period 2015 -201 9 in accordance with the criteria or meet the criteria of the test sample as many as 47 companies. The following is a list of companies in the basic industry and chemicals sector that were sampled in this study.

\subsection{Descriptive Statistics Results}

The results of descriptive statistical analysis can be seen as follows: 


\section{Procedia of Social Sciences and Humanities \\ ISSN (online) 2722-0672 \\ https://pssh.umsida.ac.id/index.php/pssh}

Table 4.3 Descriptive Statistical Analysis Results

\begin{tabular}{|c|c|c|c|c|c|c|}
\hline Model & $\mathrm{N}$ & Minimum & Maximum & Sum & Mean & $\begin{array}{c}\text { Std } \\
\text { Deviation }\end{array}$ \\
\hline F-Score & 235 & -2.3990 & 3.3216 & 462.900 & 1.9698 & 0.46829 \\
\hline Target Keuangan & 235 & 0.5485 & 0.2655 & 7.600 & 0.0323 & 0.02954 \\
\hline Stabilitas Keuangan & 235 & -0.7771 & 9.0775 & 4.900 & 0.0209 & 0.01090 \\
\hline Tekanan Ekstemal & 235 & 0.0914 & 4.0604 & 107.600 & 0.4579 & 0.25041 \\
\hline Kepemilikan Sabarm Intituri & 235 & 0.0014 & 2.7726 & 18.700 & 0.0796 & 0.07519 \\
\hline Ketidakefektifan Penzawakan & 235 & 0.2500 & 1.5000 & 148.300 & 0.6311 & 0.29311 \\
\hline Penganuh Si fat Industri & 235 & -5.6819 & 4.8496 & 0.800 & 0.0234 & 0.01817 \\
\hline Kualitas Auditor Ekstemal & 235 & 0.0000 & 1.0000 & 77.000 & 0.3277 & 0.27036 \\
\hline Pergantian Auditor & 235 & 0.0000 & 1.0000 & 24.100 & 0.2020 & 0.10339 \\
\hline Pergantian Direksi & 235 & 0.0000 & 1.0000 & 4.000 & 0.1170 & 0.02963 \\
\hline Hubungan Politik & 235 & 0.0000 & 1.0000 & 169.000 & 0.7191 & 0.45037 \\
\hline Valid N (istwize) & 235 & & & & & \\
\hline
\end{tabular}

Source: Processed data, 2020

\subsection{Classic Assumption Test Normality Test Results}

The results of the normality test using the Kolmogorov-Smirnov (KS) can be seen as follows:

Table 4.4 Results of the One-Sample Kolmogorov-Smirnov Test Normality

\begin{tabular}{|l|l|r|}
\hline \multicolumn{2}{|l|}{} & \multicolumn{1}{|c|}{$\begin{array}{c}\text { Unstandardized } \\
\text { Residual }\end{array}$} \\
\hline N & Mean & 235 \\
\hline \multirow{2}{*}{ Normal Parameters, } & Std. Deviation & .0000000 \\
\hline \multirow{3}{*}{ Most Extreme Differences } & Absolute & .29996596 \\
\cline { 2 - 3 } & Positive & .068 \\
\cline { 2 - 3 } & Negative & .057 \\
\hline Test Statistic & -.068 \\
\hline Asymp. Sig. (2-tailed) & .068 \\
\hline
\end{tabular}

Source: Secondary data processed, 2020

Based on the One-Sample Kolmogorov-Smirnov normality test in table 4.4 above, the statistical test value is 0.068 and the Asymp value. Sig (2-tailed) is 0.073 greater than 0.05 . So it can be concluded that the data is normally distributed.

\subsection{Multicollinearity Test Results}

The multicollinearity test results can be seen as follows:

Table 4.5 Multicollinearity Test Results

\begin{tabular}{|c|c|c|c|}
\hline \multirow{2}{*}{\multicolumn{2}{|c|}{ Moded }} & \multicolumn{2}{|c|}{ Collimeraty Statistio } \\
\hline & & \multirow{2}{*}{ Tolerace } & \multirow{2}{*}{ VIF } \\
\hline \multirow{11}{*}{1} & Constant) & & \\
\hline & Targes Keuangan & 838 & 1.194 \\
\hline & Sabllitas Kelangal & 905 & 1.105 \\
\hline & Tekamm Estemal & 905 & 1.105 \\
\hline & Brounnilikan Spham Inititus si & 931 & 1.075 \\
\hline & Kebidakelekcifan Pegrawasan & 892 & 1.120 \\
\hline & Pengansh Sifat Industai & 879 & 1.138 \\
\hline & Eunlitas Anditor Ekstemal & 875 & 1.143 \\
\hline & Pergantian Auditor & 977 & 1.023 \\
\hline & Pergantian Dirdes & 936 & 1.068 \\
\hline & Hubumzan Potiti: & 979 & 1.021 \\
\hline
\end{tabular}

Source: Secondary data processed, 2020

From the results of the above research, it can be concluded that all independent variables show a tolerance value $>0.10$ and a VIF value $<10$. Thus it can be stated that the independent variables used in the regression model of this study are free from multicollinearity, are reliable 
and objective.

\subsection{Heteroscedasticity Test Results}

In the heteroscedasticity test carried out in this study using the Glejser Test and also using the Scatterplot chart, namely if the significance value of the independent variable is greater than 0.05 . The results of the heteroscedasticity test can be seen as follows.

Table 4.6 Heteroscedasticity Test Results Using the Glejser Test

\begin{tabular}{|c|c|}
\hline Model & Nilai Probabilitas \\
\hline Target Keuangan & 851 \\
\hline Stabilitas Keuangan & 082 \\
\hline Tekanan Ekstemal & 974 \\
\hline Keperailikan Saham Institusi & 181 \\
\hline Ketidakeféatifan Pengawasan & .148 \\
\hline Pengaruh Sifat Industri & .141 \\
\hline Kualitas Auditor Ekstenal & 099 \\
\hline Pergantian Audtor & 066 \\
\hline Pergantian Direksi & 159 \\
\hline Hulbungan Politik & 068 \\
\hline
\end{tabular}

Source: Secondary data processed, 2020

\subsection{Autocorrelation Test Results}

The autocorrelation test used in this study used the Durbin Watson test (DWtest).

Table 4.7 Autoceralation Test Results

\begin{tabular}{|l|r|}
\hline Model & Durbin-Watson \\
\hline 1 & 1.165 \\
\hline
\end{tabular}

Source: Secondary data processed, 2020

To see the occurrence of autocorrelation or not, it can be seen through the Durbin-Watson (DW) test. Therefore, based on table 4.7 above, it is known that the Durbin-Watson (DW) value is 1.165. Compared with the significance table value of 0.05 or $\alpha=5 \%$ with a sample size of $n=$ 235 and the independent variable $10(\mathrm{~K}=10)=10,235$. It is known that the durbine watson table (attached) the value of $d u=1.8742$. So, the result of $d u$ from the table $r=D W$ is greater than the $\mathrm{d} u$ limit and DW is less than $(4-\mathrm{dU})=4-1,8742=2.1258$. Berdasarkan decision $\mathrm{du}$ $<\mathrm{dw}<4-\mathrm{du}$ is $1.8742<1.165<2,1258$ it can be concluded that there is no presence of positive and negative autocorrelation in this study.

\subsection{Results of Multiple Linear Regression Analysis}

Table 4.8 Multiple Linear Regression Analysis

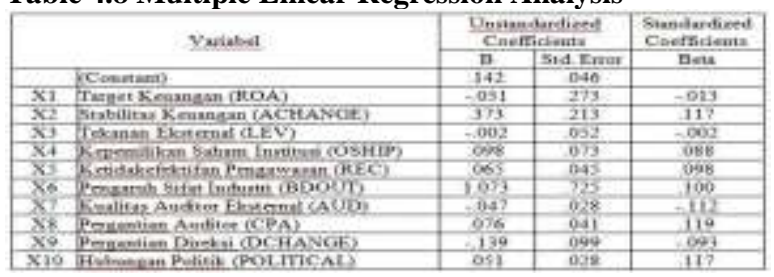

Source: Secondary data processed, 2020 
Based on table 4.8, the regression equation can be determined based on column B which is the regression coefficient of each variable. So the regression equation is:

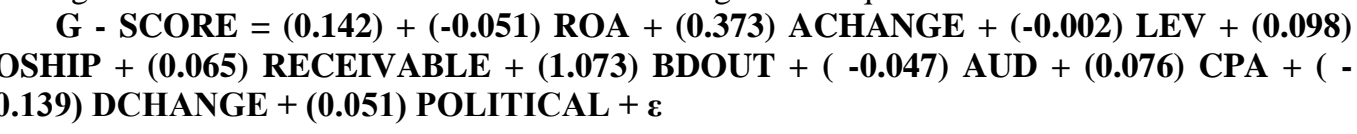

\subsection{Hypothesis Testing \\ 4.7.1 Statistical Test $\mathbf{t}$ \\ Risk effect factor of pressure on the financial statement fraud.}

Based on the research results, it is found that the financial target has a positive regression coefficient of 0,146 and sig. $t$ of 0.884 . The regression coefficient has a positive direction according to the hypothesis and the sig level. t. $>0.05$. This means that the financial targets positive effect was not significant to the financial reporting fraud, so the hypothesis of the financial targets are not supported.

Testing to variable financial stability (ACHANGE). Based on this research, financial stability variables (financial stability) had a regression coefficient negative at $-6,986$ and sig. $\mathrm{t}$ 0,000 . The regression coefficient has a negative direction, not according to the hypothesis and the sig level. t. equal to $0.000<0.05$. This means that the financial stability impact negatively significant to the financial statement fraud, so the hypothesis of the financial satabilitas not in supported.

At external pressure variable (LEVERAGE). Based on the research results, external pressure has a negative regression coefficient of $-14,570$ and sig. t. amounting to 0.000 . The regression coefficient has a negative direction, not according to the hypothesis and the sig level. $\mathrm{t}<0.05$. This means that external pressure cheating significant negative effect on the financial statements, so that the hypothesis of external pressure is not supported. On the institutional share ownership (OSHIP) variable.

Based on the research that the shareholding institutional (institutional ownership) has a negative regression coefficient of $-2,659$ and sig. t. amounting to 0.008 . The regression coefficient has a negative direction, not according to the hypothesis and the sig level. $t<0.05$. This means that stock ownership institution (institutional ownership) significant negative effect on the financial reporting fraud, so the hypothesis shareholding institutions are not in supported.

It can be concluded that the hypothesis 1 is not supported on the variable $p$ ressure (pressure) to the proxy variable financial targets positive effect was not significant, financial stability affect negatively significant, external pressure affect negatively significant, and institutional ownership affects negatively significant to the detection of financial statement fraud.

Risk effect factor and opportunity to financial statement fraud.

On the monitoring ineffectiveness variable (BDOUT). Based on the research results, ineffective monitoring has a negative regression coefficient of $-0,874$ and sig. t. of 0,383 . The regression coefficient has a negative direction, not according to the hypothesis and the sig level. $t$ $>0.05$. That is ineffectiveness supervision (ineffective monitoring) negative effect is not significant to the financial reporting fraud, so the hypothesis ineffectiveness of supervision are not in support.

Based on findings that influence the nature of the industry (nature of industry) has a negative regression coefficient of $-1,930$ and sig. t. equal to 0,045 . The regression coefficient has a negative direction, not according to the hypothesis and the sig level. $\mathrm{t}<0.05$. This means that the influence of the nature of the industry (nature of industry) negative impact significantly on fraudulent financial statements, so the hypothesis of the influence of industrial properties are 


\section{not in support.}

Based on findings that the quality of the external auditor (Quality of external auditors) had a regression coefficient positive amounting to 4,121 and sig. t. amounting to 0,000 . The regression coefficient has a positive direction according to the hypothesis and the sig level. $\mathrm{t}<$

0.05. This means that the influence of the external auditor the quality (Quality of external auditors) affect positively significant to the financial reporting fraud, so the hypothesis of the quality of the external auditor in support . It can be concluded that the quality of external auditors has a significant effect on fraudulent financial reporting.

Based on results of the study that the change of auditors (change in auditor) has a regression coefficient positive amounting to 1,893 and sig. t. amounting to 0.040 . The regression coefficient has a positive direction according to the hypothesis and the sig level. $\mathrm{t}<$

0.05 . This means that the effect of the change of auditors (change in auditor) affect positively significant to the financial reporting fraud, so the hypothetical change of auditors in carrying.

From these results it can be concluded that the greater the value of auditor turnover, will affect the potential for financial statement fraud. It can be concluded that the hypothesis 2 is supported on a variable Opportunity (Chance) was measured by proxy variables ineffective monitoring of impact negatively not significant, the nature of industry significant negative effect and Quality of external auditors affect positively significant to the detection of financial statement fraud.

\section{Risk effect factor and rationalization of the financial statement fraud.}

Based on findings that the quality of the external auditor (Quality of external auditors) had a regression coefficient positive amounting to 4,121 and sig. t. amounting to 0,000 . The regression coefficient has a positive direction according to the hypothesis and the sig level. $\mathrm{t}<$ 0.05 . This means that the influence of the external auditor the quality (Quality of external auditors) affect positively significant to the financial reporting fraud, so the hypothesis $\mathbf{3}$ quality of the external auditor in support .

\section{Risk effect factor Competence to financial statement fraud.}

Based on results of the study that the change of auditors (change in auditor) has a regression coefficient positive at 1,930 and sig. t. amounting to 0.049 . The regression coefficient has a positive direction according to the hypothesis and the sig level. $t>0.05$. This means that the effect of the change of directors (change in directors) affect positively not significant to the financial statements fraud, so the hypothesis 4 in support. From these results it can be concluded that the greater the value of director turnover, will affect the potential for financial statement fraud.

\section{Risk effect factor Arogance to financial statement fraud}

Based on findings that political relationships (political connection) has a regression coefficient negative at -1392 and sig. t. equal to 0,165 . The regression coefficient has a negative direction according to the hypothesis and sig level. $t>0.05$. This means that the influence of political relations (political connection) affect negatively not significant to the financial statement fraud, so the hypothesis 5 is not in support. From these results it can be concluded that the greater or lesser the value of the political relationship will not affect the potential for financial statement fraud. 
4.8 Determination Coefficient Test $\left(\mathbf{R}^{2}\right)$

Table 4:10 Coeficin Test Results for Determination of $\mathbf{R}^{2}$

\begin{tabular}{|c|r|r|r|r|}
\hline Model & R & R Square & Adjusted R Square & $\begin{array}{c}\text { Std. Error of the } \\
\text { Estimate }\end{array}$ \\
\hline 1 & $.770^{3}$ & .593 & .574 & .305 \\
\hline
\end{tabular}

Source: Secondary data processed, 2020

Based on table 4.10, it can be seen that the value of $\mathrm{R}^{2}$ (Adjusted $R$ Square) is 0.574 . It can be seen that the influence of the independent variables (financial targets, financial stability, external pressure, institutional ownership, ineffective supervision, the influence of the nature of the industry, the quality of external auditors, changes in auditors, changes in directors and political relations) is $57.4 \%$ on the dependent variable financial statement fraud, while the remainder is equal to $42.60 \%$ influenced by other independent variables were not examined in this study.

\subsection{Statistical Test $\mathbf{F}$}

From the test results it can be concluded that the significance value is 0.000 . Because the significance value of $0.000<0.05$ is in accordance with the basis for decision making in the $\mathrm{F}$ test, it can be concluded that the regression value is fit.

Table 4:11 Anova Test Results for Test $F$

\begin{tabular}{|c|c|c|c|c|c|c|}
\hline \multicolumn{7}{|c|}{ OVA" } \\
\hline Mo & & $\begin{array}{l}\text { Sum of } \\
\text { Squares }\end{array}$ & df & $\begin{array}{c}\text { Mean } \\
\text { Square }\end{array}$ & F & Sig: \\
\hline \multirow{3}{*}{1} & Regression & 30.410 & 10 & 3.041 & 32.583 & $.000^{\circ}$ \\
\hline & Residual & 20.906 & 224 & .093 & & \\
\hline & Total & 51.315 & 234 & & & \\
\hline
\end{tabular}

Source: Secondary data processed, 2020

\section{Conclusion}

\subsection{Conclusion}

Based on the results of data analysis in the research that has been done, pressure on variables proxy for financial targets positive effect was not significant, financial stability affect negatively significant, external pressure affect negatively significant, and institutional ownership affects negatively significant to the detection of financial statement fraud No manufacturing company sector basic industry and chemicals listed on the Indonesia Stock Exchange (BEI) for the period 2015-2019. Opportunity measured by variables proxy ineffective monitoring of impact negatively not significant, the nature of industry significant negative effect and Quality of external auditors affect positively significant to the detection of financial statement fraud no manufacturing company sector basic industry and chemicals listing Indonesia Stock Exchange (BEI) in the period 2015-2019. Rationalization measured by proxy variables change in the auditor affect significant positive to the detection of financial statement fraud to detection of financial statement fraud p No manufacturing company sector basic industry and chemicals listing Indonesia Stock Exchange (BEI) in the period 2015-2019. Competence is measured by proxy variables change in directors influence positively and significantly to the detection of financial statement fraud $\mathrm{p}$ No manufacturing company sector basic industry and chemicals listing Indonesia Stock Exchange (BEI) in the period 2015-2019. Arogance measured by proxy variables political connection effect is not significant negative to the detection of financial 


\section{Procedia of Social Sciences and Humanities \\ ISSN (online) 2722-0672 \\ https://pssh.umsida.ac.id/index.php/pssh}

statement fraud $\mathrm{p}$ No manufacturing company sector basic industry and chemicals listing Indonesia Stock Exchange (BEI) in the period 2015-2019.

\subsection{Limitations}

This research has been attempted and carried out in accordance with scientific procedures, however, it still has limitations, namely in this study the variable capability was measured using DCHANGE. This measurement is considered too justifying or there is a bad indication of the performance of the old directors. This is because the change of directors is influenced by many factors, not only due to the performance of the old directors who are indicated to have committed fraud but can occur because of being appointed to the board of commissioners, assigned to other companies, death or other factors.

\subsection{Suggestion}

Based on the description of the discussion and the conclusions obtained, the following are suggestions that researchers can convey for further research, namely that it is expected to use a broader research object so that it can generalize research results for all companies listed on the IDX, it is hoped that it can add proxy variables of fraud pentagon such as capital turnover, structure of organization, and so on as well as measuring the dependent variable with other formulas so that the coverage of the variables to be tested becomes wider and then it is expected to conduct research on different objects so that it can produce comprehensive results and can see how the influence of the variables is compared research on different objects.

\section{References}

[1] ACFE (2018): Report To the Nations 2018 Global Study on Occupational Fraud and Abuse Asia Pacific Edition (Vol.10). Retrieved from https://www.acfe.com/uploadedFiles/ACFE_Website/Content/rttn/2018/RTT N-Asia-PacificEdition.pdf

[2] Agoes, Sukrisno . 2017 . Auditing: Practical Guidelines for Accountant Examination by Public Accounting Firms . Issue 5 . South Jakarta : Four Salemba.

[3] Zelin , Cintia . 2018 . Pentagon Fraud Analysis in Detecting Fraud Financial Statements Using the Fraud Score Model . Essay. Faculty of Economics, Islamic University of Indonesia: Yogyakarta.

[4] Jensen, MC, \& Meckling, WH (1976). Theory of the firm: Managerial behavior, agency costs and ownership structure. Journal of Financial Economics, Vol. 3 No 4, 305-360. Available athttps: //doi.org/10.1016/0304- 405X (76) 90026-X

[5] Arens, Alvin.A Randal J. Elder and Mark S. Beasley. 2015. Auditing and Assurance Service, Fifteenth Ediition. Volume 1. Jakarta : Erlangga Publisher.

[6] Cressey, D. 1953. Other people's money; a study in the social psychology of embezzlement. Glencoe, IL: FreePress.

[7] Skousen, CJ, \& Twedt, BJ (2009). Fraud in Emerging Markets: A Cross Country Analysis.

[8] Dechow, PM, Ge, W., Larson, CR, \& Sloan, RG (2011). Predicting Material Accounting Misstatements. Contemporary Accounting Research, Vol. 28 No. 1, 17-82. Available athttps: //doi.org/10.1111/j.1911-3846.2010.01041.x

[9] Heviana, Ema. 2017. Fraudulent Financial Reporting: Testing the Pentagon's Fraud Theory at StateOwned Enterprises (BUMN) listed on the Indonesia Stock Exchange (BEI) for the 2012-2016 Period. Essay. Faculty of Economics and Business, State Islamic University (UIN) Syarif Hidayatullah: Jakarta.

[10] Legowo, Indar Satria. 2019. The Influence of Pentagon Fraud Factors and Audit Committee Expertise on Fraudulent Financial Reporting. Essay. Accounting Study Program, Faculty of Economics and Business, Pancasakti University: Tegal. 


\section{Procedia of Social Sciences and Humanities \\ ISSN (online) 2722-0672 \\ https://pssh.umsida.ac.id/index.php/pssh}

[11] Saptarini, Galih Devi . 201 9. Early Warning System for Financial Report Fraud Based on Pentagon Fraud Analysis . Faculty of Economics, Indonesian Islamic University, Yogyakarta. Mendeley . Journal of Accounting. 3 (2) .

[12] Priantara, Diaz. 2013. Fraud Auditing \& Investigation . Mitra Wacana Media, Jakarta.

[13] Rahmanti, MM, \& Daljono. (2013). Fraud Detection of Financial Statements through Pressure and Opportunity Risk Factors (Case Study of Companies Receiving Sanctions from Bapepam 2002-2006 Period). Journal of Accounting, Faculty of Economics and Business , Diponegoro University, Vol. 2 No. 2, 1-12.

[14] Sihombing, KS, \& Rahardjo, SN (2014). Diamond Fraud Analysis in Detecting Financial Statement Fraud: An Empirical Study of Manufacturing Companies Listed on the Indonesia Stock Exchange (BEI) 2010-2012, Diponegoro Journal of Accounting Vol. 03 No. 02.ISSN (Online): 2337 - 3806.

[15] Nuraina, Elva. 2012. The Influence of Institutional Ownership and Company Size on Debt Policy and Firm Value (Study on Manufacturing Companies Listed on the IDX). Madiun: Journal of Business and Economics . Vol. 19, No. 2.

[16] Agusputri, Hanifah and Sofie. 2019. Factors Affecting Frauduluent Financial Reporting Using Pentagon Fraud Analysis. Faculty of Economics and Business, Trisakti University: Jakarta. Journal of Tax Information, Accounting and Public Finance Vol 14 No. July 2, 2019: 105-124.

[17] Skousen, et al. 2009. Detecting and Predicting Financial Statement Fraud: The Effectiveness of the Fraud Triangle and SAS No.99. In CJ Skousen, KR Smith, \& C. j. Wright, Advances in Financial Economics (pp. 53-81). Bingley : Emerald Group Publishing Limited.

[18] Chaney, PK, Faccio, M., \& Parsley, D. (2011). The Quality Of Accounting Information In Politically Connected Firms. Journal of Accounting and Economics, Vol. 51: No. 1:58-76.

[19] Sugiyono. 2013. Statistics For Research. The 27th edition. Bandung : Alfabeta Publisher.

[20] Sugiyono . 2016. Quantitative Research Methods, Qualitative and $R \& D$. 26th printing . Bandung : Alfabeta Publisher.

[21] Ghozali, Imam. 2016. Multivariete Analysis Application with IBM SPSS 23 Program (8th Edition) . VIII printing. Semarang: Diponegoro University Publishing Agency .

[22] Ghozali. (2013). Multivariate Analysis Application with IBM SPSS 21 Program (Fifth Edition). Semarang: Diponegoro University Publishing Agency. 